\title{
Exosomes as a promising tool for research and molecular diagnostics of myelopro- liferative disorders
}

\author{
Anna N. Parfenenkova ${ }^{1}$, Ildar M. Barkhatov ${ }^{2}$, Anton A. Kremlev ${ }^{2}$, Olga A. Epifanovskaya ${ }^{2}$, Andrey N. Gorshkov ${ }^{3}$, \\ Vera V. Vysochinskaya ${ }^{3}$, Mikhail P. Grudinin ${ }^{3}$, Anton A. Kornev ${ }^{4}$, Boris V. Afanasyev ${ }^{2}$ \\ ${ }^{1}$ St. Petersburg State University of Chemical Pharmaceutics, St. Petersburg, Russia \\ ${ }^{2}$ Raisa Gorbacheva Memorial Research Institute of Pediatric Oncology, Hematology and Transplantation, Pavlov First Saint \\ Petersburg State Medical University, St. Petersburg, Russia \\ ${ }^{3}$ A. Smorodintsev Research Institute of Influenza, St. Petersburg, Russia \\ ${ }^{4}$ St. Petersburg National Research University, Russian Academy of Sciences, St. Petersburg, Russia
}

Dr. Ildar M. Barkhatov, PhD (Medicine), Raisa Gorbacheva Memorial Research Institute of Pediatric Oncology, Hematology and Transplantation, Pavlov First Saint Petersburg State Medical University, L. Tolstoy St 6-8, 197022,

St. Petersburg, Russia
Phone: +7 (911) 7782785

E-mail: i.barkhatov@gmail.com

Citation: Parfenenkova AN, Barkhatov IM, Kremlev AA et al. Exosomes as a promising tool for research and molecular diagnostics of myeloproliferative disorders. Cell Ther Transplant 2019; 8(2): 74-81.

\section{Summary}

Detection of molecular markers characteristic to malignant cells is the key task of molecular genetic studies in oncohematology, aiming for timely diagnosis of the diseases and evaluation of their progression, like as relapse risks. Exosomes are among the most promising objects for such studies. They represent a fraction of extracellular membrane particles ranging from 30 to $150 \mathrm{~nm}$ in size, presumably containing such tumor markers. These vesicles are found in blood serum and other biological fluids, being important participants in cell-cell interactions capable of transferring various biopolymers, which can also mediate the reprogramming of the functions of the recipient cells and influence the development of resistance to therapy. On the basis of exosomes, one may optimize such a novel diagnostic approach as fluid biopsy which is minimally invasive, and, therefore, can also be used as a specific monitoring tool for prediction of tumor relapse development.

As a part of this work, we aimed for finding whether exosomes can potentially influence the results of minimal residual disease determination in the patients with chronic myeloid leukemia (CML).
In order to study the characteristics of exosomes, we used the method of sequential ultracentrifugation followed by analysis of the morphological and functional characteristics of exosomes. In addition, the possibility of horizontal transfer of the chimeric $B C R-A B L$ transcript from leukemic to stromal cells through the exosomal fraction was analyzed.

The results of our in vitro study show evidence of horizontal transfer of oncogene mRNA from malignant to normal stromal cells. In conclusion, considering the fact that bone marrow mesenchymal stromal cells (MSCs) play the main role in hematopoiesis regulation, which forms a niche for hematopoietic stem cells (HSCs), we suggested that extracellular vesicles may act as a possible source of detectable oncogene transcripts and their migration into the cells of microenvironment.

\section{Keywords}

Extracellular vesicles, exosomes, gene overexpression, molecular markers, cell-cell interactions, mesenchymal stem cells, mRNA transport, $B C R-A B L$, chronic myeloid leukemia, minimal residual disease, liquid biopsy. 


\section{Introduction}

Almost all cells of the human body secrete into the extracellular space a variety of vesicles, that are classified into ectosomes, apoptotic bodies, microvesicles and exosomes. The most interesting of them are exosomes, i.e., microvesicles, whose dimensions do not exceed $150 \mathrm{~nm}$ [1]. They are formed in the cells along the endosomal pathway with the formation of distinct endosomes, and, therefore, are of intracellular origin [2]. Exosomes are active participants in the intercellular communication system and provide for the transfer of their contents, being protected with vesicular membranes. The first evidence for the opportunity of mRNA transfer using exosomes was obtained by J. Ratajczak (2006) [3], who treated mononuclear cells from murine bone marrow with exosomes of embryonic stem cells, which harbor a lot of mRNA encoding Oct4 transcription factor in their cytoplasm, thus leading to increased Oct4 synthesis in the recipient cells. Since then, many researchers have confirmed the possibility of exosome-mediated horizontal transfer of nucleic acids.

The spectrum and significance of the fundamental biological processes in which exosomes take part, the opportunity of translating this knowledge into clinical practice determine the steadily growing interest of workers in this area of biomedicine. A promising direction of such studies is a more detailed profiling of nucleic acids carried by exosomes of blast cells, in order to search for potential markers of malignancies that could provide higher sensitivity and specificity under conditions of minimally invasive diagnostic procedures (the so-called liquid biopsy), as demonstrated for some solid tumors [4]. In the future, it would be possible to estimate the minimal residual disease based on exosome samples, but today there are a number of obstacles for clinical usage of this approach. First of all, there are difficulties with reliable purification of homogeneous exosomal fraction free of impurities, absence of standard isolation protocols, as well as lack of large studies confirming sensitivity of these techniques, and their comparison with approved methods of laboratory diagnostics.

Chronic myeloid leukemia (CML) cells are the model subject of our study. CML is a clonal myeloproliferative disease in which the cells of the myeloid lineage undergo massive clonal expansion [5]. The chimeric (fusion) BCR-ABL gene is formed as a result of reciprocal translocation between chromosome 9 and 22 [6]. Such a mutation is found in $90 \%$ of blast cells from CML patients [7] and is associated with formation of the so-called Philadelphia chromosome [ $\mathrm{t}$ (9; $22), \mathrm{Ph}+$. Highly active tyrosine kinase, encoded by BCR$\mathrm{ABL}$, influences the rates of DNA homologous recombination and reparation, thus promoting acquisition of additional mutations and chromosomal aberrations by the $\mathrm{Ph}+$ cells, and also causes their excessive proliferation. As a rule, the activity of the BCR-ABL protein is necessary and sufficient to maintain the leukemic phenotype $[8,9]$. This aberrant protein is shown to disturb the adhesion of leukemic blasts to the cells from bone marrow microenvironment [10], it changes the features of migration, and alters maturation of myelopoiesis progenitor cells. There are several different variants of proteins detectable in $\mathrm{t}(9 ; 22)$ mutation, but the most common transcripts in CML are b3a2 and b2a2, resulting in the formation of a protein with molecular mass of $210 \mathrm{kDa}$ (p210, Mbcr) $[11,12,13]$. Thus, $B C R-A B L$ is a typical marker of chronic myeloid leukemia.

The purpose of this work was an in vitro study of horizontal transfer of the chimeric $B C R-A B L$ p210 transcript to the mesenchymal stromal bone marrow cells (MSCs) from healthy donors using exosomal fraction of extracellular microvesicles in model, aiming for evaluation of their potential significance for detection of minimal residual disease (MRD) in the patients with chronic myeloid leukemia.

\section{Materials and methods}

\section{Cultural methods}

K562 cells transduced with the LVT-TagGFP2 vector (Evrogen) were used as a producer and source of exosomes. The cells were positive for the $B C R-A B L$ p210 marker and for the eGFP fluorescent protein. To expand the biomass, the cells were cultured in RPMI-1640 medium, supplied with 10\% FBS, $100 \mu \mathrm{g} / \mathrm{mL}$ of streptomycin, $100 \mathrm{U} / \mathrm{mL}$ of penicillin (“BioloT”, St. Petersburg).

The mesenchymal stromal cells (MSCs) were isolated from the bone marrow of healthy donors according to a standard protocol in a Ficoll density gradient.

\section{Enrichment and isolation of the K562-derived exosomes}

K562 cells were cultured in serum-free nutrient medium Panexin basic, Serum Replacement with Defined Components (Pan Biotech, Germany). Twenty-four hour later, the exosomal fraction was enriched, using a protocol based on differential ultracentrifugation, according to Thery et al., [14]. In brief, the cells were separated by centrifugation at $300 \mathrm{~g}$ for $10 \mathrm{~min}$. Further procedures were performed at $4^{\circ} \mathrm{C}$. The resulting supernate was centrifuged for 20 minutes at $2000 \mathrm{~g}$, in order to remove cellular debris. Apoptotic bodies were harvested at $10.000 \mathrm{~g}$ for 45 minutes. Sedimentation regimen for the resulting supernate was dependent on the volume of centrifugation tube $(70 \mathrm{~mL})$, lasting for $<10$ hours at $100000 \mathrm{~g}$. The pellet was washed in PBS, and the vesicles were precipitated at $100000 \mathrm{~g}$, then dissolved in $1000 \mu \mathrm{l}$ of serum-free medium Panexin basic and gently vortexed. The samples were stored at $-80^{\circ} \mathrm{C}$.

\section{Analysis of the particles obtained}

The isolated particles were analyzed using laser correlation spectroscopy approach. In the course of sample preparation, the exosomes were dissolved in $1000 \mu \mathrm{l}$ of serum-free Panexin basic Medium. A 7- $\mu \mathrm{L}$ aliquote was then dispersed in $\mathrm{dH}_{2} \mathrm{O}$ at a 1:100 ratio. Spectroscopic measurements were made in a Zetasizer NanoZS laser correlation spectrometer (measured particle range: $0.3 \mathrm{~nm}$ to $10 \mu \mathrm{m}$, Malvern Instruments, UK). Thus, we checked the biomaterial for presence of exosomes after plotting the particle size distribution in the sample measured by means of dynamic laser beam scattering. The diameter of particles was calculated using Zetasizer Software 7.11 software (Malvern Instruments). Zeta potential was also measured, in order to determine stability of the 
particles and to evaluate their ability to interact with other biological systems,

Morphological features of the particles were assessed by transmission electron microscopy with negative contrasting (JEM-100S, Jeol, Japan).

\section{Co-cultures of MSCS and K562, contamination control}

Co-cultivation of K562 and MSC was performed in a 24well plate with semi-permeable polycarbonate membranes (pore diameter - $0.4 \mu \mathrm{m}$, Biofil, China) under similar culture conditions (RPMI-1640 medium, supplied with 10\% FBS, $100 \mu \mathrm{g} / \mathrm{mL}$ of streptomycin, $100 \mathrm{U} / \mathrm{mL}$ of penicillin). The confluence of MSCs on plastic plates was $80 \%$, the concentration of K562 cells, $1 \mathrm{mln} / \mathrm{ml}$.

To assess the contamination with K562 cells, the MSC fraction was examined by flow cytofluorimetry (FACSCanto, BD, USA). Antibodies were used against the surface marker of CD45 leukocytes, and the detection of eGFP was also evaluated. Cell viability was assessed by means of vital 7-AAD staining. In parallel, potential contamination with K562 cells was monitored by confocal microscopy (LSM 710, Carl Zeiss, Germany).

\section{MSC transfection with K562-derived Exosomes}

The experiments with transfer of $B C R / A B L$ transcript were carried out in a 24-well plate at the MSC concentration of 20.000 cells per well. The cells were incubated for 24 hours under standard conditions, with subsequent addition of 300 $\mu \mathrm{l}$ serum-free growth medium containing exosomes derived of $70 \times 10^{6} \mathrm{~K} 562$ cells per well followed by 24 -hour incubation under similar conditions.

\section{Analysis of the $B C R-A B L$ expression levels using real-time quantitative PCR (RT-PCR) and agarose gel electrophoresis}

Total mRNA from both cells and exosomes was isolated by guanidine-phenol-chloroform extraction using TriZ Reagent (Inogene, Russia) according to the manufacturer's instructions. Eleven $\mu \mathrm{L}$ of extracted RNA were subjected to reverse transcription using the RevertAid First Stand cDNA Syntesis Kit (Thermo Fisher Scientific). For each cDNA sample, multiplex PCR was performed for the BCR-ABL p210 and
$A B L 1$ genes using primers and probes (Table 1). The relative expression level of the $B C R-A B L$ transcript was determined by RT-PCR against the $A B L 1$ reference gene in duplicate by means of the ICycler iQ5 device (Bio-Rad, USA), using the amplification reagent kit M-428 (Syntol, Russia). The PCR conditions were as follows: $10 \mu \mathrm{l}$ of PCR reaction mixture containing dNTP mix $2.5 \mathrm{mM}$ each, $10 \times$ PCR buffer, 5 Units of Taq-DNA polymerase and $2.5 \mu \mathrm{l}$ of $25 \mathrm{mM} \mathrm{MgCl} 2$, supplemented with 5 pmol of Taqman probes specific for the BCR$A B L$ p210 and $A B L 1$ genes. The primer and TaqMan probe sequences used for RT-PCR, and the sizes of resulting amplicons are shown in Table 1 . To estimate absolute quantities of $B C R-A B L$ and $A B L 1$ transcripts, we used the Mbcr $B C R-A B L$ Kit (Inogene, Russia) whose standard samples were used to plot appropriate calibration curves. The final PCR reaction volume was $25 \mu \mathrm{l}$. The following amplification mode was used: initial incubation at $95^{\circ} \mathrm{C}$ for 5 minutes followed by 45 two-step cycles $\left(95^{\circ} \mathrm{C}, 15 \mathrm{sec} ; 60^{\circ} \mathrm{C}, 1 \mathrm{~min}\right)$. Fluorescent signal was registered at $60^{\circ} \mathrm{C}$ at the FAM and HEX channels. The mRNA expression ratio was calculated as copies of $B C R$ $A B L \mathrm{p} 210 /$ copies of $A B L 1 \times 100 \%$, and the results were expressed as percentage of $B C R-A B L$ to $A B L$ transcripts.

Separation of the $B C R-A B L$ and $A B L 1$ fragments obtained by amplifying CDNA samples with the same primers was performed by horizontal electrophoresis in $2 \%$ agarose gel stained with ethidium bromide.

\section{Results}

\section{Analysis of selected particles (exosomes)}

As seen from Figure 1, the largest number of vesicles in the sample corresponded to presumed size of exosomes [1]. At the same time, the results of the study of 15 samples showed that the distribution of the average sample size by diameter is in the range of 51.8 to $107.0 \mathrm{~nm}$, with a mean value of $78.96 \pm 20.03 \mathrm{~nm}$. Two peaks may be discerned at the distribution curve, the largest one $(82.5 \%)$ corresponds to stable subfraction with average $\mathrm{ZP}$ value of $-29.3 \pm 7.4 \mathrm{mV}$ (Fig. 2), which indirectly indicates their stability.

Upon morphological studies, the particles correspond to exosomes, as confirmed by electron microscopy (Fig. 3) within the expected size range and with general exosome-like morphology, consistent with the previous studies [1].

Table 1. Nucleotide sequences of primers and Taqman probes used for quantitative assays of chimeric $B C R-A B L$ p210 transcripts

\begin{tabular}{|l|l|l|l|l|}
\hline $\begin{array}{l}\text { Gene } \\
\text { studied }\end{array}$ & Forward primers $\left(5^{\prime} \rightarrow 3^{\prime}\right)$ & Reverse primers $\left(5^{\prime} \rightarrow 3^{\prime}\right)$ & TaqMan fluorescent probes & $\begin{array}{l}\text { Amplicon } \\
\text { size }(\text { base } \\
\text { pairs })\end{array}$ \\
\hline $\begin{array}{l}B C R-A B L \\
\text { m-bcr } \\
(\mathrm{p} 210)\end{array}$ & TCCGCTGACCATCAAYAAGGA & CACTCAGACCCTGAGGCTCAA & FAM-CCCTTCAGCGGCCAGTAGCATCTGA-RT01 & 149 \\
\hline$A B L 1$ & TGGAGATAACACTCTAAGCATAACTAAAGGT & GATGTAGTTGCTTGGGACCCA & R6G-CCATTTTTGGTTTGGGCTTCACACCATT-RT01 & 124 \\
\hline
\end{tabular}


Size Distribution by Number

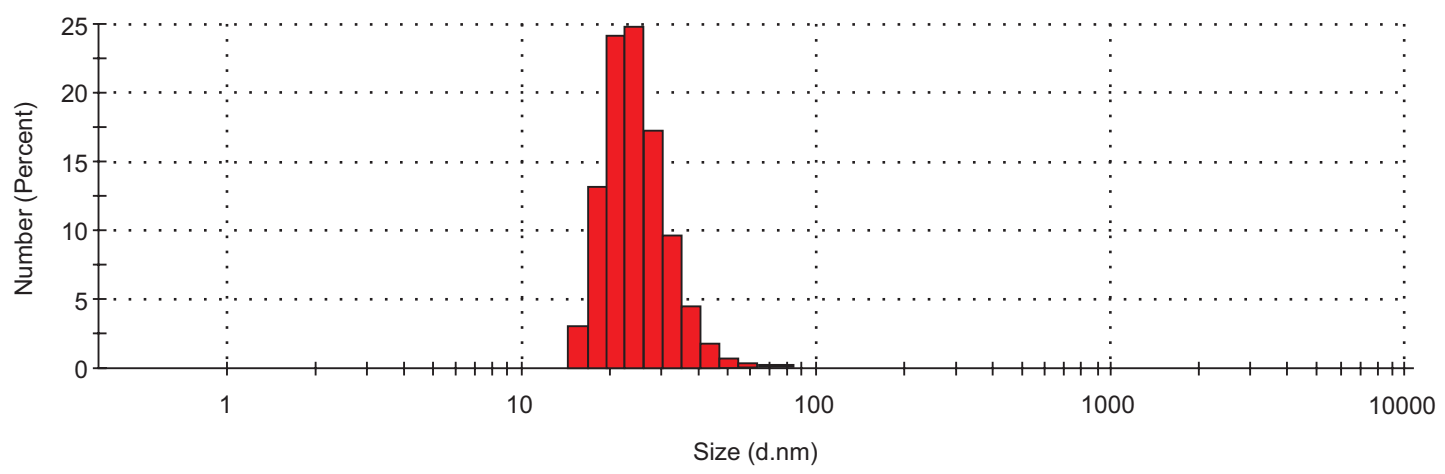

Figure 1. Size distribution of the K562-derived nanovesicles. The diameter for the largest number of particles is indicated

Zeta Potential Distribution

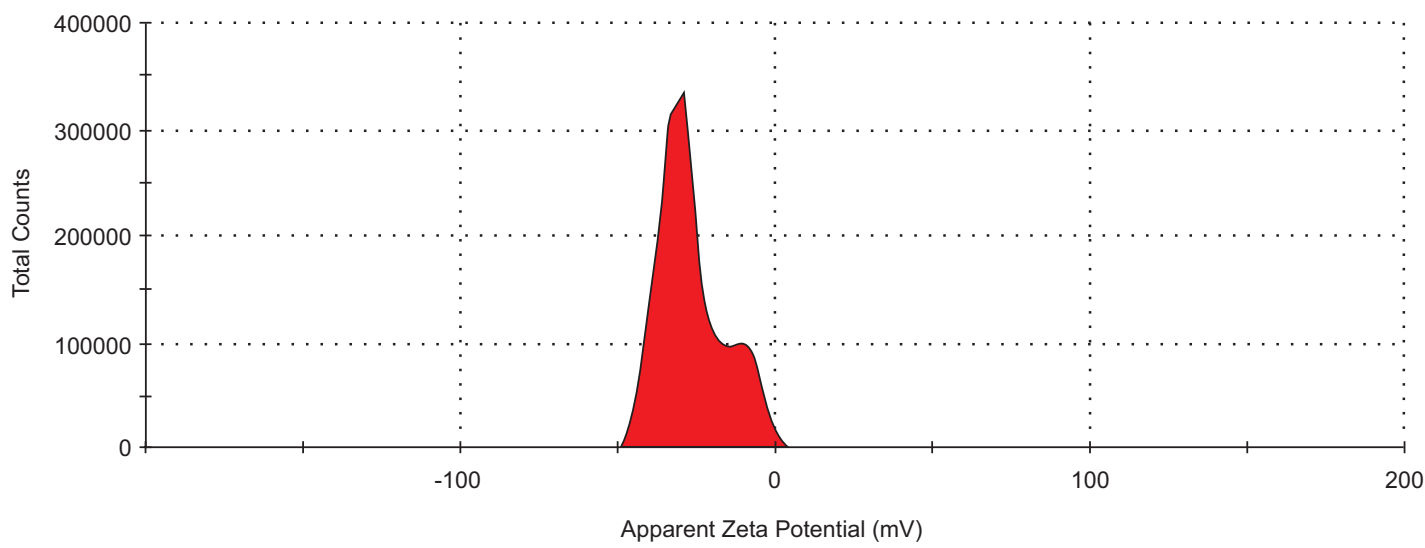

Figure 2. Zeta-potential of the isolated nanovesicles
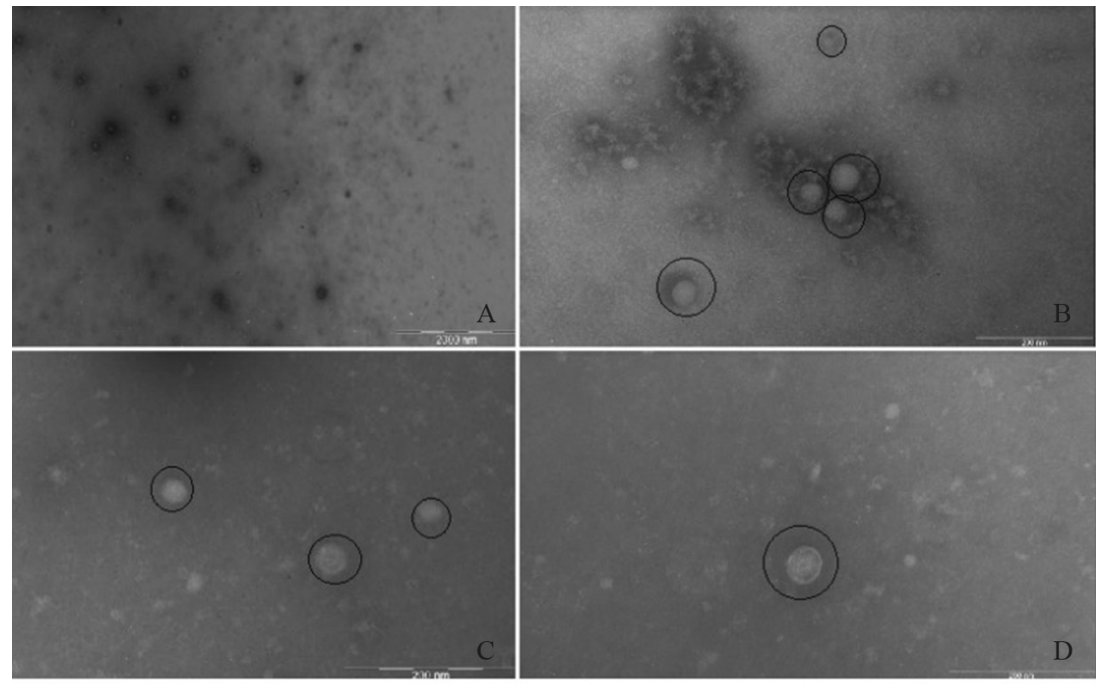

Figure 3. Transmission electron microscopy of the vesicles detected by negative contrasting: $A$, general view of preparation; B, C, D - exosome-like particles (marked with circles). The length of scale lines is $200 \mathrm{~nm}$ 


\section{Co-cultivation of MSCs and $\mathrm{K} 562$ cells potential contamination issues}

When assessing the possible contamination of the MSC fraction, we conducted an assessment of the presence of hematopoietic markers in the culture of adherent cells, which results in data indicating the absence of cells with the CD45+/ eGFP+ phenotype (Fig. 4). In addition, the probability of MSC contamination by hematopoietic cells was assessed by confocal microscopy, which showed similar results (Fig. 5).

\section{Relative contents of $B C R-A B L$ in K562 cells, exosomes, and transfected MSCS}

According to the qPCR results, expression levels of BCR$A B L$ chimeric transcript in exosomes ranged from 44.42 to 863.79 copies/mL of conditioned medium, with a median value of 154.42. Nineteen K562 cell samples and six exosome preparations were included into the study. Comparable values were detected, when assessing relative expression of the $B C R-A B L$ gene in K562 cells and exosomes ( $\mathrm{p}>0.05)$ as seen from Fig. 6.
$A$

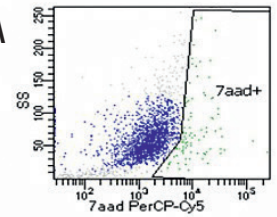

B

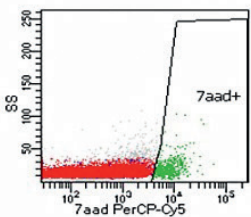

C

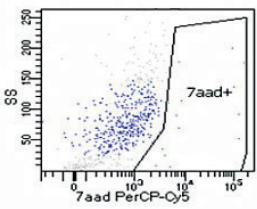

D

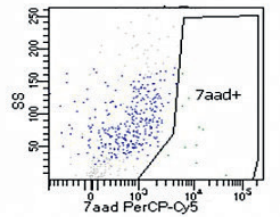

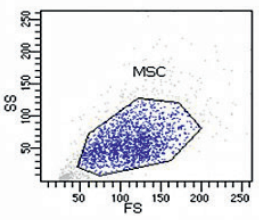
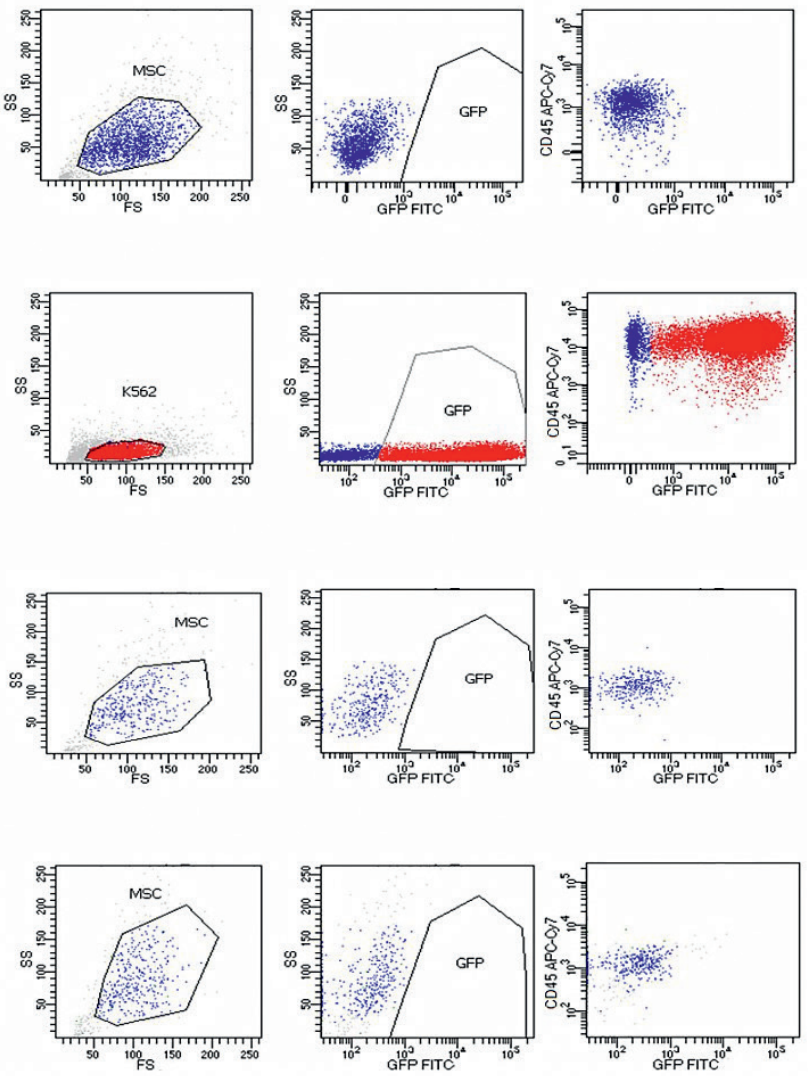

Figure 4. Flow cytometric phenotype of the cells under study.

A: Negative control - MSC of healthy donors, CD45-, eGFP-; B: Positive control - K562 line cells, BCR-ABL p210 +, CD45 +, eGFP +; C, D: MSCs of healthy donors and K562 cell lines following co-cultivation through a semi-permeable membrane. K562 cells are not revealed.
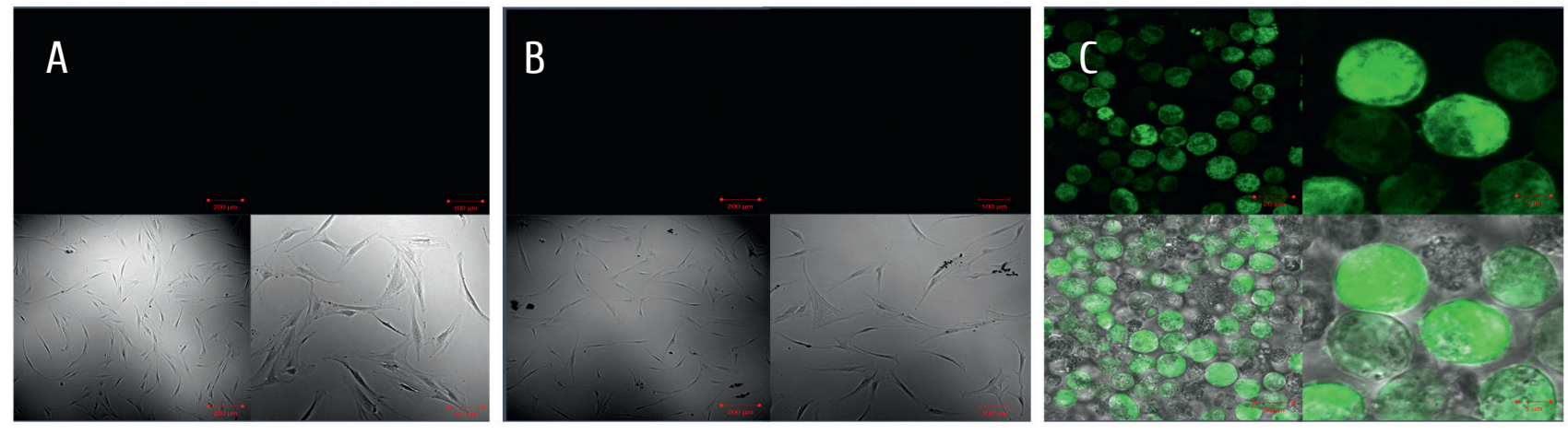

Figure 5. Confocal microscopy of MSC/K562 co-cultures.

A: MSC of healthy donors and K562 cell line, cocultivated through a semi-permeable membrane, K562 not detectable; B: Negative control, MSC from healthy donors, CD45-, eGFP-; C: Positive control, K562 cells: BCR-ABL p210 +, CD45 +, eGFP +. 
After cocultivation of K562 and MSCs, the relative content of $B C R-A B L$ in recipient mesenchymal cells was 0.03 to $11.4 \%$ of ABL levels, with a median of $0.29 \%(\mathrm{~N}=8)$. High-quality verification of the target amplicon is confirmed by agarose gel electrophoresis gel (Fig. 7).

As a result of exosome-mediated transfection, the relative content of the chimeric transcript in the MSC of healthy donors $(n=9)$ ranged from 0.01 to $15.88 \%$, with a median value of $0.11 \%$, which corresponds to a positive result when determining MRD in CML patients, and confirms a direct involvement of exosomes into the $B C R / A B L$ transfer.

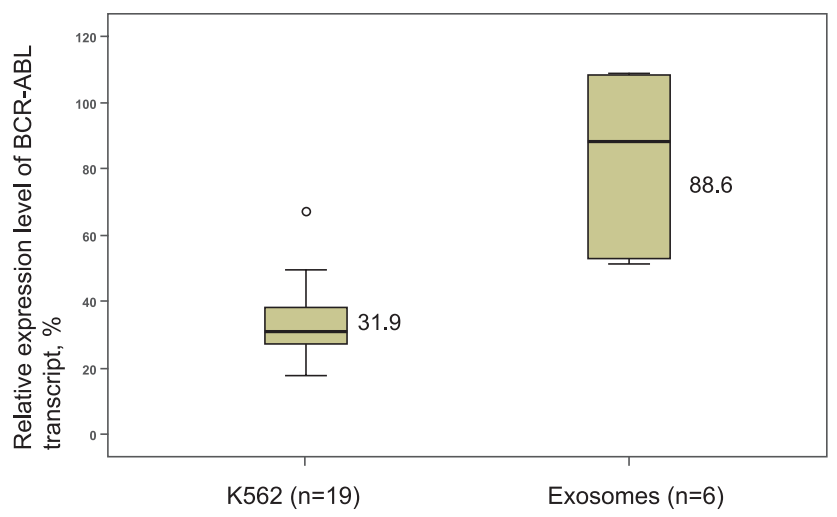

Figure 6 . The results of RT-PCR show relative content of $B C R-A B L$ p210 in $\mathrm{K} 562$ cell line and exosomes isolated from them

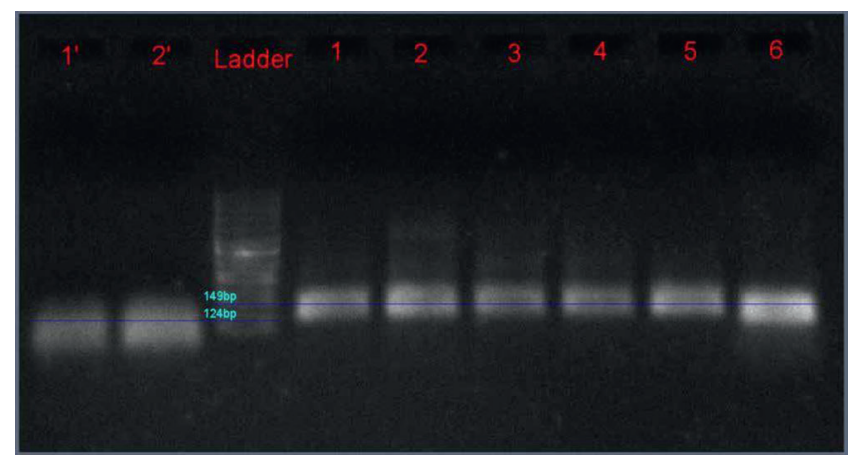

Figure 7. Detection of $B C R-A B L$ p210 transcript (wells $1 \div 6)$ and $A B L\left(1,2^{\prime}\right)$ by electrophoresis performed in a $2 \%$ agarose gel

\section{Discussion}

In the frame of present work, we were able to demonstrate the opportunity for horizontal exosome-mediated transfer of chimeric $B C R-A B L$ p 210 transcript from malignant cell producers to the in vitro exposed human stromal bone marrow cells. Of sufficient importance, this oncogene transfer can be detected and monitored using standard molecular genetic techniques used in routine laboratory diagnostics.

We assume that the communications between stromal microenvironment and leukemic cells could be mediated, e.g., by exosomal fraction of microvesicles derived from malignant cells. Apparently, there is a wide spectrum of physiological processes modulated by exosomes, and its more detailed study is of great interest. It is still an open question about the role of exosomes in this intercellular interactions and duration of their in vivo persistence in extracellular fluids, and, in particular, in biological materials used for clinical diagnostics. Studies on the stability of circulating RNAs indicate its localization in exosomes, and also indicate to integrity of these nucleic acids within these vesicles. An opportunity of their determination in mice with xenografts was shown after 7 weeks after implantation of cancer cells, and incubation of serum samples at room temperature for 24 hours had a minimal effect on circulating RNA levels [15]. For comparison, miRNAs are stable only within several minutes [16], which makes them unsuitable candidates for assessing the risk of developing a relapse. Obviously, the vesicular membrane provides some resistance of nucleic acids to external enzymatic effects. Our in vitro results of the cocultivation experiments suggest that, at least, during co-cultures, the CML miRNA marker encapsulated in exosomes for 48-72 hours is preserved in the culture media under study.

The development of new diagnostic strategies based on vesicular nanoparticle data could be a promising research project aimed at optimizing a number of clinical laboratory diagnostic approaches.

\section{Conclusions}

In the course of differential ultracentrifugation, extracellular microvesicles were obtained, which correspond to exosomes by their morphological parameters. In exosomes derived from the K562 cell line, relative expression of the chimeric $B C R-A B L$ gene is observed at a level comparable to the producer cells.

According to the results of cocultivation of producer cells with stromal cells, and by direct transfection of them with isolated microvesicles, it was established that the mRNA of the $B C R-A B L$ p 210 gene can be transferred into mesenchymal stromal cells of the bone marrow via exosomes.

Quantitative assessment of this transcript allows the similar order of sensitivity as the level required for obtaining positive result of the minimal residual disease detection, which indicates the potential of exosomes to contribute to the results of MRD determination.

\section{Conflicts of interests}

No potential conflicts of interests are reported.

\section{References}

1. Shah R, Patel T, Freedman JE. Circulating extracellular vesicles in human disease. New Engl J Med. 2018; 379(10): 958-966.

2. Thery C, Zitvogel L, Amigorena S. Exosomes: composition, biogenesis and function. Nature Rev Immunol. 2002; 2(8): 569-579.

3. Ratajczak J, Miekus K, Kucia M, Zhang J, Reca R, Dvorak P, Ratajczak MZ. Embryonic stem cell-derived microvesicles reprogram hematopoietic progenitors: evidence for horizontal transfer of mRNA and protein delivery. Leukemia. 2006; 20(5): 847-856. 
4. Melo SA, Luecke LB, Kahlert C, Fernandez AF, Gammon ST, Kaye J, LeBleu VS, Mittendorf E.A, Weitz J, Rahbari N, Reissfelder C, Pilarsky C, Fraga MF, Piwnica-Worms D, Kalluri R. Glypican-1 identifies cancer exosomes and detects early pancreatic cancer. Nature. 2015; 523: 177-182.

5. Druker BJ, Talpaz M, Resta DJ et al. Efficacy and safety of a specific inhibitor of the BCR-ABL tyrosine kinase in chronic myeloid leukemia. N Engl J Med 2001;344:1031-1037.

6. Melo JV. The diversity of BCR-ABL fusion proteins and their relationship to leukemia phenotype. Blood. 1996;88:2375-2384.

7. Cortes J E, Talpaz M, Beran M, O’Brien SM, Rios MB, Stass S, Kantarjian HM. Philadelphia chromosome-negative chronic myelogenous leukemia with rearrangement of the breakpoint cluster region. Long-term follow-up results. Cancer. 1995; 75:464-470.

8. Daley GQ, Van Etten RA, Baltimore D. Induction of chronic myelogenous leukemia in mice by the P210 bcr/abl gene of the Philadelphia chromosome. Science. 1990;247: 824-827.

9. Pear WS, Miller JP, Xu L, Pui JC, Soffer B, Quackenbush RC, Pendergast AM, Bronson R, Aster JC, Scott ML, Baltimore D. Efficient and rapid induction of a chronic myelogenous leukemia-like myeloproliferative disease in mice receiving P210 bcr/abl-transduced bone marrow. Blood. 1998;92: 3780-3792.

10. Raimondo S, Saieva L, Corrado C, Fontana S, Flugy A, Rizzo A, De Leo G, Alessandro R. Chronic myeloid leukemia-derived exosomes promote tumor growth through an autocrine mechanism. Cell Commun Signal. 2015;13:8. doi: 10.1186/s12964-015-0086-x.

11. Pane F, Interieri M, Quintarelli C, Izzo B, Muccioli GC, Salvatore F. Bcr-Abl genes and leukemic phenotype: from molecular mechanisms to clinical correlations. Oncogene 2002; 21: 8652-8667.

12. Moumen A, Dehbi H, Kottwitz D, El Amrani M, Bouchoutrouch N, El Hadi H, Quessar A, Benchekroun S, Nadifi S, Sefrioui H. Quantitative real-time polymerase chain reaction as an efficient molecular tool for detecting minimal residual disease in Moroccan chronic myeloid leukemia patients. Genet Mol Res 14.1 (2015): 1044-1055.

13. Thijsen, S FT, Schuurhuis G, van Oostveen J, Ossenkoppele G. Chronic myeloid leukemia from basics to bedside. Leukemia. 1999; 13(11): 1646-1674.

14. Thery C, Amigorena S, Raposo G, Clayton A. Isolation and characterization of exosomes from cell culture supernatants and biological fluids. Current Protoc Cell Biol. 2006. Chapter 3. Unit 3.22. DOI: 10.1002/0471143030.cb0322s30.

15. Li Y, Zheng Q, Bao C, Li S, Guo W, Zhao J, Chen D, $\mathrm{Gu}$ J, He X, Huang S. Circular RNA is enriched and stable in exosomes: a promising biomarker for cancer diagnosis. Cell Res. 2015;25(8):981-984.

16. Taylor DD, Gercel-Taylor C. The origin, function, and diagnostic potential of RNA within extracellular vesicles present in human biological fluids. Front Genet. 2013 Jul 30;4:142. doi: 10.3389/fgene.2013.00142. 


\title{
Экзосомы как перспективный объект для исследова- ния и молекулярной диагностики миелопролифера- тивных заболеваний
}

\author{
Анна Н. Парфененкова ${ }^{1}$, Ильдар М. Бархатов ${ }^{2}$, Антон А. Кремлев ${ }^{2}$, Ольга А. Епифановская ${ }^{2}$, Андрей Н. Горшков ${ }^{3}$, \\ Вера В. Высочинская ${ }^{3}$, Михаил П. Грудинин ${ }^{3}$, Антон А. Корнев ${ }^{4}$, Борис В. Афанасьев ${ }^{2}$ \\ ${ }^{1}$ Санкт-Петербургский Государственный Химико-фармацевтический Университет, Санкт-Петербург, Россия \\ ${ }^{2}$ НИИ детской онкологии, гематологии и трансплантологии им. Р. М. Горбачевой, Первый Санкт-Петербургский \\ государственный медицинский университет им. И. П. Павлова, Санкт-Петербург, Россия \\ ${ }^{3}$ Научно-исследовательский институт гриппа имени А. А. Смородинцева, Санкт-Петербург, Россия \\ ${ }^{4}$ Санкт-Петербургский национальный исследовательский Университет РАН, Санкт-Петербург, Россия
}

\section{Резюме}

Ключевой задачей молекулярно-генетических исследований в онкогематологии является выявление молекулярных маркеров, характерных для трансформированных клеток с целью диагностики заболеваний, своевременной оценки их прогрессии, а также риска развития рецидива. Одним из перспективных объектов для изучения, предположительно содержащих такие маркеры, являются экзосомы мембранные частицы, размеры которых находятся в интервале от 30 до 150 нм. Данные везикулы являются важными участниками межклеточных взаимодействий и способны к трансферу различных биополимеров, которые также могут опосредовать репрограммирование функций клеток-реципиентов, оказать влияние на развитие резистентности к терапии. На основе экзосом может быть оптимизирована такая диагностическая методика как жидкостная биопсия, являющаяся малоинвазивной, и потому также может быть использована в качестве частного мониторинга для предикции развития рецидива.

С целью изучения характеристик экзосом мы использовали метод последовательного ультрацентрифугирования с последующим анализом морфологических и функциональных характеристик экзосом. В рамках данной работы мы попытались выяснить, могут ли экзосомы потенциально оказывать влияние на результаты определения минимальной остаточной болезни у пациентов с хроническим миелолейкозом. Учитывая тот факт, что основная роль в регуляции кроветворения принадлежит мезенхимным стромальным клеткам (МСК) костного мозга, формирующим нишу для гемопоэтических стволовых клеток (ГСК), мы предположили, что возможным источником выявляемого транскрипта могут выступать в том числе как персистирующие в костном мозге внеклеточные везикулы, так и их миграция в клетки микроокружения. Результаты нашего исследования указывают на возможность горизонтального переноса гиперэкспрессирующихся молекулярных маркеров между опухолевыми и стромальными клетками in vitro.

\section{Ключевые слова}

Внеклеточные частицы, экзосомы, генная гиперэкспрессия, молекулярные маркеры, межклеточные взаимодействия, мезенхимные стволовые клетки, транспорт мРНК, BCR-ABL, хронический миелоидный лейкоз, минимальная остаточная болезнь, «жидкая» биопсия. 